\title{
"Hy wat is en wat was en wat kom": Die God van betrokkenheid volgens Openbaring ${ }^{1}$
}

J A du Rand

(Randse Afrikaanse Universiteit)

\begin{abstract}
The one who is and who was and who is to come: The God of commitment according to the book of Revelation

The theocentricity of Revelation makes an imperative of the placement of the committed One who is and who was and who is to come in the centre of history of mankind. God's character, as depicted in Revelation, is developed through interaction with all creation. The response of nondivine characters to their creator shapes the hearer's/readers' perception of God, who is both revealed and shrouded in mystery through the apocalyptic visions. Through direct, indirect and interdividual characterisation, the focus falls on the expression "who is to come" to emphasise God's commitment, through the sacrifice of the Lamb.
\end{abstract}

\section{PROBLEMATIEK IN DIE UNIEKHEID}

Vanuit Christelike perspektief is besinning oor God volgens Bybelse getuienis van wesenlike belang. Dit dien nie slegs as noodsaaklike brugbouer om die verhouding tussen $\mathrm{Ou}$ en Nuwe Testament te verstaan nie maar open ook nuwe perspektiewe wat die Christelike geloof nog opwindender maak. So 'n vraag na God volgens die getuienis van die boek Openbaring is nie 'n koffietafelboekvraag nie. Openbaring bied die antwoorde nie glansryk en oppervlakkig aan nie maar onthul dit in die voue van apokaliptiese teologiese kontoere. Dit verg hermeneutiese kontrole én waagmoed om tot die gevolgtrekking te kom dat die laaste boek in die kanonieke Nuwe Testament 'n God-boek is.

Een van die kenmerkende beskrywings van God volgens Openbaring is juis die uitdrukking: Hy wat is en wat was en wat kom in 1:4, 8 en 4:8. Die drieledige patroon word driekeer gebruik en die gewysigde tweeledige patroon: "Hy wat is en wat was" tweekeer in 11:17 en 16:5.

Die drieledige formaat sou nie as sodanig as uniek beskryf kan word nie en tog bevat dit 'n moment van uniekheid. Dit is nie uniek nie omdat dit ' $n$ Johannese interpretasie is van die Godsnaam JHWH, soos ons dit vind in Eksodus 3:14: "Ek is wat Ek is". Latere Judaïstiese tra-

\footnotetext{
${ }^{1} \mathrm{Na}$ ongeveer vier dekades van akademiese saamwees en saamwerk dra ek deur hierdie bydras graag my hulde oor aan Wil Vosloo, gewaardeerde vriend en kollega, in wie se teologiese binneste 'n evangeliese hart klop.
} 
disies het dié uitdrukking verstaan as 'n interpretasie om God se ewigheid mee uit te druk (Filo, Mos 1:75).

Die Palestynse Targoem, Pseudo-Jonatan, parafraseer dié Godsnaam soos volg: "Ek is wat Ek was en sal wees" na aanleiding van Eksodus 3:14, en "Ek is die Een wat is en wat was en Ek is die Een wat Ek sal wees" na aanleiding van Deuteronomium 32:29 (Sib Or 3:16). David Aune (1983:81) toon ook aan dat die drieledige uitdrukking in drie verskillende tydvorme, naamlik verlede, hede en toekoms, tipies is van wat gesê is oor die Griekse gode.

Die uniekheid van die uitdrukking fokus daarop dat volgens die voorkomste in Openbaring 1:4 en 8 die derde deel daarvan nie die futurum is van die werkwoord "om te wees" nie, maar die teenswoordige deelwoord van die werkwoord "om te kom". Alhoewel die Johannese aanwending ooreenstem met dié van die Targoems om God se teenswoordige bestaan te benadruk, wyk hy af van die gebruiklike "Hy wat

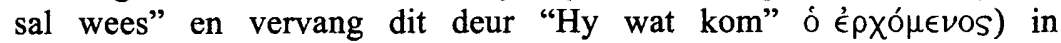
Openbaring 1:4 en 8. Waarom sou hy die gebruiklike "Hy wat sal wees" vervang deur die deelwoordvorm: "Hy wat kom"? 'n Mens sou dit (oor)vereenvoudig kon beantwoord deur te sê dat, netsoos in Engels, dié teenswoordige deelwoordvorm op die toekoms kan slaan soos in "the age to come" of "the coming age". Sou daar nie egter 'n teologiese lading agter die taalkundige voorkeur van Johannes skuil nie? Dit moet bepaal word aan die hand van 'n ontleding van die breër Godsvoorstelling volgens ' $n$ verantwoorde lees van Openbaring.

\section{VERSTAAN WORD GEDIEN DEUR DIE DOEL}

Bloot die wyse waarop God geteken word volgens Openbaring dwing die interpreteerder van dié boek om dit binne ' $n$ wyer raamwerk te interpreteer voordat enige geldige gevolgtrekkings gemaak kan word. Só 'n selektiewe raamwerk moet onder andere in ag neem wat die doel daarvan vir die eerste historiese lesers was, asook die algemene hermeneutiese verstaan van die boek.

Oor die moontlike historiese situasie kan geen volledige of voldoende gevolgtrekkings geformuleer word nie omdat die omstandighede nie meer feitelik geverifieer kan word nie. Dit is egter duidelik dat die eerste historiese lesers ' $n$ spanning beleef ten opsigte van hul identiteit. Vanuit religieuse perspektief gesien is hulle burgers van God se koninkryk, maar volgens daaglikse ervaring ondervind hulle vervolging en sosiale verwydering van die samelewing (Collins 1977:241-256; Frend 1965; Du Rand 1990:199-207). Só 'n spanning vereis, volgens Schüssler Fiorenza, “... consistent resistance or endurance” (1991:119). Die lesers van Openbaring word deurgaans opgeroep om die magte van Rome as instrument van Satan te sien teenoor die allesbepalende krag van God. In dié opsig is Openbaring 'n voorbeeld van versetliteratuur waarin die 
voorstelling van God die dominante plek inneem. Die navolgers van die Lam moet versoeking en kompromieë weerstaan, al kos dit ook lyding. Die skynbaar oorwonnenes moet leef uit die bewussyn van oorwinnaars omdat hulle geestelik asemhaal uit die simboliese universum dat God regverdig is en aan hulle reg sal laat geskied (Barr 1984:50; Harrington 1993). Die voorstelling van God bied daaglikse drakrag in só 'n situasie.

Vroeëre kommentatore het Openbaring hoofsaaklik beskou as Johannes se antwoord op die vervolging van Christene deur Rome (Beckwith 1922; Bowman 1968:7; Swete 1977). Sommige resente eksegete meen egter dat daar nie van 'n direkte vervolging onder Rome sprake is nie maar eerder van 'n "perceived crisis", 'n spanning en verwagting van gevaar (Collins 1976:84; Cothenet 1995:37). Daarvolgens bied Johannes 'n antwoord op die verwerping en onderdrukking van Christene deur ongelowiges. Dit is geleë in die konstituering van 'n Christelike gemeenskap van sosiale radikalisme wat beteken dat die Christene hulle onttrek van die Grieks-Romeinse gemeenskap om sekuriteit en identiteit te vind in 'n onafhanklike verwagting van 'n onmiddellike oordeel oor hul teenstanders sowel as hul eie verlossing (Da Silva 1993:61). In dié opsig voorsien Openbaring 'n boodskap van hoop en bemoediging in krisistye maar daag ook die loues, geestelik lammes en lakses uit om gefokus te bly.

Volgens Smalley (1994) is die doel van die boek Openbaring om liefde deur middel van oordeel tuis te bring by 'n gemeenskap wat van buite vervolg en van binne bedreig word deur allerlei onenigheid en dwaling. Openbaring is ' $n$ uitnodiging tot hoop in ' $n$ bedreigde situasie (Kealy 1987:34-36).

Openbaring het bepaald 'n teleologiese gerigtheid. Op 'n apokaliptiese reis wat gebruik maak van simboliek, retoriek en buite-wêreldse projeksies word die lesers uitgedaag om die riskante alledaagse te trotseer. Die natuurlike en logiese word getransformeer in die lig van 'n gekonstrueerde simboliese universum om 'n leefbare verstaansraamwerk te bied.

Om saam te vat. 'n Christelike profeet Johannes het aan die einde van die eerste eeu $\mathrm{nC}$ in unieke apokaliptiese styl sy visioene opgeteken. Dit handel oor die ontvouing van God se plan vir mens en geskiedenis waarin die oorwinnende Lam koers en bestemming gee. Daarom word God op ' $n$ besondere wyse voorgestel as die bestierder van tyd en ewigheid. Hy is die transendente, maar ook die teenwoordige betrokkene. Openbaring is nie net ' $n$ apokaliptiese tekening van die triomf van die Lam nie, maar ook 'n profetiese bemoediging aan die lesers om aan die woord van God en die getuienis van Jesus vas te hou (1:3). In die proses van die ontvouing van die geskiedenis ontplooi God se oordeel sowel as sy verlossing. God bly in beheer en het, by wyse van spreke, die laaste sê (Aune 1986:65-96). 
In die lig van bogenoemde beskrywing kan tereg gesê word dat die boek Openbaring 'n krisisgeskrif is met die oog op ' $n$ bepaalde situasie. Dit bevat die geloofsantwoord van en aan 'n vervolgde en vervreemde groep Christene in 'n knellende sosio-politieke situasie. Uit só 'n situasie groei 'n Godsbegrip wat aan die apokaliptiese hoop drakrag gee. Dit maak immers die daaglikse krisis draaglik. 'n Karakterisering van God volgens Openbaring se narratief stel lesers in staat om daagliks betekenisvol te volhard.

\section{KARAKTERISERING VAN GOD}

Karakterisering is besonder gekompliseerd in Bybelse narratiewe omdat definisies van karakters geformuleer is na aanleiding van die voorkomste daarvan in fiksie. Die fundering van karakterisering lê egter in die sekulêre literêre teorie.

Om by ' $n$ werkbare definisie van karakter uit te kom is nogal problematies. G Prince (1987:12) definieer dit as "an existent endowed with anthromorphic traits and engaged in anthropomorphic actions; an actor with anthropomorphic attributes" (vgl ook Roberts 1948). In só 'n definisie val die klem eensydig op die plot en aksie en word die karakters bloot aangewend om die plot te laat voortstu in die narratief. Sou die draak of dier uit die see as karakters geklassifiseer kan word solank hulle net menslike eienskappe vertoon? Hoe sou dit die karakterisering van God raak? Moet Hy "wat op die troon sit", die "Alfa en Omega", eers die menslike horisonne oorsteek om as karakter geken te word? Is die "gans anderse" God bloot 'n menslike perfeksie met antropomorfiese eienskappe? Wat dan van onantropomorfiese voorstellings van God, byvoorbeeld in die Ou Testament? ' $n$ Mens dink aan die brandende bos!

S Chatman (1978:42) definieer karakter as "a paradigm of constructed traits that the reader attaches to a name". F Burnett (1978:42) steun op Chatman as hy sê dat die leser "accumulates indicators from the text and compiles a composite view of a character who may at times transcend the text and seem to possess individuality" (1993:16). En tog moet ons in gedagte hou dat die karakter veel meer en groter is as die somtotaal van sy/haar literêre brokstukke! Daarom sê D B Growler (1993:21) tereg: "The text generates the characters, but a reader must apprehend them". Johannes se visualisering van God stel die leser in staat om God beter te verstaan maar laat ook nog genoeg oor aan die misterie sodat God nie volledig vasgepen kan word nie. Geen karakterisering kan volledig aan God reg laat geskied. Sy volheid kan nie in een narratief vasgevat word nie.

Die verhouding tussen literêre karakters en die werklike persone vorm wesenlik deel van die problematiek van karakterisering. Langs die weg van nabootsing of simulering (Donaldson 1993:87; Weinsheimer 1979:185-211) is gepoog om die literêre karakter uit te bring by die 
werklike persoon. M Bal (1985:81) praat selfs van "paper people" as sy karakters in 'n verhaal definieer. God is meer as 'n "paper figure" volgens Openbaring. Hy is volgens geloofsuitgangspunt histories maar bo enige menslike bevatlikheid en ons ontvang slegs grepe en flitse van Hom volgens sy betrokkenheid in die menslike geskiedenis. Die leser konstrueer daaruit 'n voorstelling van God wat korrespondeer met dié van die outeur van Openbaring. Só 'n herkonstruksie is betroubaarder as die simulering van 'n literêre karakter met 'n historiese persoon.

In die klassieke Griekse karakterisering is gebruik gemaak van deskriptiewe of direkte karakterisering volgens die Aristoteliese model (Burnett 1993:3-28), asook van die indirekte waarvolgens die lesers afleidings moes maak oor die karakter. Laasgenoemde kategorie laat die karakter toe om deur sy dade en woorde 'n indruk te laat by die lesers. Dit lei daartoe dat Bybelse karakters meestal in tipes ingedeel kan word volgens die waardes van 'n bepaalde gemeenskap. Die karakters volgens Openbaring funksioneer meestal as tipes met ' $n$ retoriese doel. Die leser word deel van die verhaal en moet assosieer of dissosieer met karakters. Die karakters van Openbaring is allermins staties of slegs op een dimensie (Martin 1986:118). Johannes self is so 'n karakter. Selfs die twee getuies, twaalf stamme of honderd-vier-en-veertigduisend, alhoewel sogenaamd naamloos, vind hul identiteit in hul verhouding tot Hom wat was en wat is en wat kom.

In die karakterisering van God volgens Openbaring speel die volgende riglyne 'n rol: repetisie, akkumulasie van eienskappe, transformasies en veral die onderlinge verhoudinge met andere (Bal 1985:85-86; Day 1995). Volgens die eerste-eeuse Palestynse kultuur is karakterisering grotendeels te bepaal volgens 'n karakter se verhoudinge met ander. D McCracken noem dit "interdividuality" waarvolgens karakters "are formed, reformed and revealed in dialogic interaction at a moment of crisis"'. Só 'n benadering hou bepaalde implikasies in vir die karakterisering van God volgens Openbaring. Die nie-goddelike karakters vind hul identiteit in hul verhoudinge met God. God word sigbaar in sy verhoudinge met mense en gebeure. Hy staan in 'n verhouding met Johannes, die ouderlinge, die engele, die gemeentes, die draak, die diere uit die see en aarde, die honderd vier en veertig duisend en die konings en sakemanne, om enkeles te noem.

${ }^{2}$ Character in the boundary: Bakhtin's interdividuality in Biblical narratives. Semeia 63 (1993), 29. In die Sotho-Tswana kultuur geld dieselfde beginsel soos vervat in die volgende bekende spreuk: Motho umuntu ga uBantu: "Ek bestaan omdat ek behoort". Vergelyk C Rotz, the One who sits on the throne. Individual perspectives of the characterization of God in the book of Revelation. Johannesburg: RAU (Unpublished D Litt et Phil) 1998, 93. 
God bestaan onafhanklik van enige beskrywings of voorstellings van Hom in Openbaring. Daarom kan geen karakterisering van God daarop aanspraak maak om 'n "teografie" te wees nie. Volgens direkte karakterisering word veral gelet op betitelings. So word God byvoorbeeld in Openbaring 16:5-7 genoem: regverdig, heilig, almagtige, betroubaar en reg. Dit dra by tot 'n tekening van God volgens Openbaring. Naamgewing is nog só 'n bydraende aspek van direkte karakterisering (Weinsheimer 1979:187; Beck 1993:143-158). God word nie altyd theos genoem nie maar name wat simbolies ryker betekenis dra. Van die bekendstes is byvoorbeeld: die "Alfa en die Omega" (1:18; 21:6); "Die Een wat is en wat was en wat kom" $(1: 4,8 ; 4: 8 ; 11: 17$; $16: 5)$; "Die Een wat op die troon sit" (4:9; $5: 1 ; 7: 13 ; 6: 16 ; 7: 15 ; 21: 5)$. God se name is gekontekstualiseer. Die enkelvoudigheid in interpretasie is tot niet omdat die een tot een korrespondensie tussen naam en karakter nie gehandhaaf kan word nie. "The plurality of anaphoric name-substitutes pluralizes character. The anaphor is a characterization as well as a name", is die mening van C Rotz (1998:99). Die verhouding tussen Christus en God is kompleks volgens Openbaring as gevolg van anaforiese benaming. Albei deel byvoorbeeld die anaforiese naam "Alfa en die Omega".

'n Verdere aspek van direkte karakterisering is fisiese beskrywing. Ten einde die verhoogde Christus se majesteit en heerlikheid fisies te beskryf, teken Johannes sy hare só wit soos wol, soos sneeu; sy oë soos vuur wat vlam; sy voete soos geelkoper wat in 'n smeltoond gloei en sy stem soos die gedruis van 'n groot watermassa (1:14-16). Die simboliek is in so 'n geval sprekend. Die onuitspreeklikheid van 'n fisiese voorstelling van God lê in die fyn balans tussen sy transendensie as "God op sy troon" en sy betrokkenheid as "die Een wat was en wat is en wat kom". Nog 'n aspek van direkte karakterisering is evaluering. Die geïmpliseerde outeur, verteller, stemme vanaf die hemel en engele gee evaluerings wat lig werp op God.

Die inhoud van die teologiese plot van Openbaring word afgelei van die makro-narratief waarvolgens die heerskappy van God op aarde gevestig en erken word soos dit reeds in die hemel bestaan (Du Rand 1997:59-75). Indirekte karakterisering word veral bepaal deur die onderlinge verhouding en wisselwerking tussen gebeure en karakters; die betekenis van nie-verbale kommunikasie, soos byvoorbeeld gebare ${ }^{3}$, die rol van houding, om byvoorbeeld neer te val in aanbidding $(1: 17 ; 5: 8$, $14 ; 11: 16 ; 19: 4)$ of om 'n sittende posisie in te neem $(3: 21 ; 22: 1,3)$ en

${ }^{3}$ Dink maar net aan die rol van die regterhand: Jesus hou die sewe sterre in sy regterhand (1:16) en die ruiter op die swart perd hou 'n skaal in syne 6:5). Toe Johannes by die verhoogde Here se voete neerval, vat Jesus met sy regterhand aan hom (1:17). 
die bekendstelling van 'n karakter deur dialoog, gesprek en redevoering, soos byvoorbeeld deur vertellings, beskrywings, bevele, selfbekendmakings, aankondigings, liedere en klagtes, om van die belangrikstes te noem (Gill 1990:7; Vanni 1991:348-372).

Bogenoemde keuse uit die literêre karakterisering kan op Openbaring toegepas word in die bepaling van 'n beskrywing van die karakter van God. Die interaksie van verskillende karakters in die vertelwêreld met God werp lig op 'n moontlike voorstelling van God. Die leser het 'n wrewelrige afkeer van die optrede van die bose, maar ontwikkel 'n hegter lojaliteit aan Hom wat was en wat is en wat kom.

\section{DIE GOD VAN BETROKKENHEID}

Al die karakters in die narratief volgens Openbaring ontvang hul karakterisering volgens hul verhouding met Hom wat was wat is en wat kom. Die skepping loof en aanbid Hom, terwyl die Sataniese magte hul karakterisering vind in hul negatiwiteit. Hul rol is hoofsaaklik parodies.

Volgens direkte karakterisering word veral deur betiteling 'n reeks titels en beskrywings aan God toegeken wat veelseggend is (Malina 1995:262). Die liedere in Openbaring maak die grootste bydrae: In 4:811 word God se heiligheid, waardigheid en almag besing; in 5:9-13 sy waardigheid, loof, eer, heerlikheid, krag en verlossingsvoorsiening deur die beskikbaarstelling van die Lam; in 7:10-12 sy voorsiening van die Lam, lof, heerlikheid, wysheid, dank, eer, mag en sterkte; in 11:15-18 sy koningskap, almag, oordeel en toorn; in 12:10-12 sy redding, mag, koningskap en gesag; in 15:3-4 sy grootheid, wonderbaarlikheid, almag, reg, betroubaarheid regverdigheid en heiligheid; in 16:5-7 sy regverdigheid, heiligheid, oordeel en betroubaarheid; in 19:1-8 sy oorwinning, heerlikheid, mag, regverdigheid, reg, oordeel, heerskappy en almag.

Alhoewel lofprysing nie as sodanig 'n betiteling van God genoem kan word nie, dra dit dinamies by tot die voorstelling van God in Openbaring. Die lofprysing in die hemelse hofsaal skep ' $n$ atmosfeer om die teosentriese aard van Openbaring te benadruk. Tiperend is die stem uit die hemel wat roep: "Prys die Here" (19:1). Dit kan die hallelujakoor genoem word $(19: 1,3,4,6)^{4}$. Die amen as antwoord is ewe treffend (19:4). Dit bevestig eerbetoon aan God. Slegs in 4:8 en 6:10 word heilig op God betrek. Die heiligheid van die profete (22:6), engele $(14: 10)$ en die stad $(11: 2)$ is slegs met betrekking tot God te verstane. Sy heiligheid gee identiteit aan sy volgelinge $(5: 8 ; 8: 3,4 ; 11: 18 ; 13: 7,10 ; 16: 6 ; 17: 6)$. God se heiligheid word gereflekteer in sy regverdige oordele. Daarom noem die martelare aan die voet van die altaar Hom heilig (6:10).

4 Volgens die Nuwe Testament word die Griekse woord ả $\lambda \lambda \eta \lambda$ ovïá slegs in Openbaring 19:1, 3, 4 en 6 aangetref. 
God se mag ontplooi deurgaans in die oorwinningsverhaal volgens Openbaring. Sy mag manifesteer kosmies en eskatologies volgens die kommentaar deur die kore $(4: 11 ; 5: 2 ; 7: 12 ; 11: 17)$. Deur sy mag voltrek God sy oordele oor Babilon in die vorm van plae, siekte en natuurelemente (18:10). Sy mag en heerlikheid gaan hand aan hand $(5: 13)^{5}$. Deur sy mag vestig God sy heerskappy op aarde soos wat dit reeds in die hemel bestaan (11:17).

Sy grootheid en wonderbaarheid word veral in die lied van Moses en die Lam (15:1v) besing. Na die ontplooiing van God se toorn oor die heidennasies word die hemelse Koning erken in die nuwe Jerusalem (Reid 1996:14-24). Sy grootheid ken geen grense (11:17). In die verband van aanbidding word God se heerlikheid gewoonlik genoem (5:1vv). Die hele skepping gee eer en heerlikheid aan God. Die hallelujakoor (19:1-8) besing God se heerlikheid omdat Hy regverdig en reg is in sy oordeel oor die "sedelose vrou". Die tempel is vol van die heerlikheid van God $(15: 8)$ en die nuwe Jerusalem wat neerdaal reflekteer God se onuitspreeklike heerlikheid (21:11).

Die vier en twintig ouderlinge en die engele bring onderskeidelik aan God die eer. Hy is alleen eerbaar om dit te ontvang $(4: 11 ; 5: 12)$.

God is ook die regverdigheid self in sy oordele. Al die nasies sal Hom kom aanbid omdat Hy regverdig is. Sy regverdige dade gee uitdrukking aan sy verlossing, heerlikheid en mag. Hy is regverdig omdat Hy betroubaar is $(15: 3 ; 16: 7)$. Daarom vloei beloning of straf regverdig voort uit sy betroubare en regverdige oordeel omdat dit sy toorn vergestalt (14:10). Babilon moet byvoorbeeld "die beker met die wyn van God se gloeiende toorn" drink (16:19) omdat hul geen berou of bekering toon nie. God verkies bekering bo alles. Telkens volgens die oordeelsvisioene is bekering die eintlike doel $(9: 20 \mathrm{v} ; 16: 9,11)$. Dit beklemtoon net dat die mens vir of teen God kan kies. Die wesenlike van God se toorn is allermins wraak maar liefde. Sy doelwit is eerder die verlossing en bekering van die mens. Daarop volg dank- en eerbetoning deur die lewende wesens, ouderlinge en engele $(4: 9 ; 7: 12 ; 11: 17)$.

Die konstruktiewe betrokkenheid van God by die mens deur verlossing en oordeel te bewerk, ontketen reaksie by veral vyf groeperinge: die vier en twintig ouderlinge $(4: 11 ; 5: 10)$; die vier lewende wesens $(5: 10)$; engele $(7: 3,12)$; hemelse stemme $(11: 15 ; 12: 10 ; 19: 1,5)$ en die ontelbare menigte $(7: 10 ; 19: 6)$. Dit beklemtoon nog eens die universaliteit van God. God is God van alle nasies, stamme, tale en mense.

Hy wat was en wat is en wat kom is teenwoordig by sy eie in die nuwe Jerusalem. Hy is sigbaar deur die lig (21:3). God het self sy skepping vernuwe en nou sy woonplek by die mense gemaak. Sy betrokken-

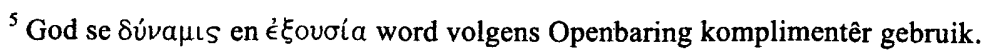


heid het 'n nuwe formaat en gestalte aangeneem. Hy is nie net "sigbaar" en betrokke by spesifieke rituele handelinge nie maar vul die hele nuwe Jerusalem op aarde (Boring 1989:218; Rotz 1998:380).

Naamgewing is ' $n$ belangrike aspek van direkte karakterisering. Iemand se persoon en mag is ten nouste verbind aan sy/haar naam in die antieke wêreld. Om aan God 'n naam toe te ken, het beteken om vorm te gee aan wat van God se optrede en handelinge waargeneem is. Die belangrikste name wat aan God toegeken is, word vervolgens net genoem terwyl die Een wat was en wat is en wat kom kortliks bespreek word.

Alreeds in 1:4-5 word die Goddelike triniteit beklemtoon. Die naam Alfa en Omega $(1: 8,17 ; 21: 6 ; 22: 13)$ is waarskynlik terug te voer tot Jesaja (44:6) waar dit ook funksioneer as Goddelike selfaanduiding. Dié naam fokus op God en die Skepper van alles wat leef, die Here van die heelal en geskiedenis (Bauckham 1993:23-28), vanaf skepping tot voleinding. Die eskatologiese fokus van Openbaring plaas die karakterisering van God in direkte perspektief. Die begin en einde is nie slegs gebeure nie maar 'n persoon ${ }^{6}$. Die naam die Almagtige kom sewe keer voor in Openbaring $(1: 8 ; 4: 8 ; 11: 17 ; 15: 3 ; 16: 7 ; 19: 6 ; 21: 22)$. Dit kom in vier gevalle in kombinasie voor met die naam die Een wat was en wat is en wat kom $(1: 8 ; 4: 8 ; 11: 17)$. Dié naam roep die Ou Testamentiese "Here van die leerskare" in gedagte en fokus op die Here se onbeperkte mag en sy kontrole oor alles en almal. Dit is egter nie 'n tipiese aardse magsoewereiniteit nie, maar 'n kruissoewereiniteit omdat God die geskiedenis beheer deur die kruisrol van die Lam volgens Openbaring (Johnson 1993:127-139).

God word ook Here genoem, die ekwivalent van die Ou Testamentiese JHWH. Dié naam fokus op God se betrokkenheid by verhoudinge. Hy is die Here van almal en alles. Die naam God sou by die Griekse hoorders/lesers 'n tipiese politeïstiese konnotasie kon oproep. Diegene vanuit Judaïstiese agtergrond het God as die lewende beskou $(7: 2)$, die persoonlike en betrokke God $(5: 10 ; 7: 3,10 ; 7: 12 ; 12: 10 ; 19: 1$, $5,6)$. Persone en gebeure vind hul definisie op grond van hul verhouding met dié lewende God. God word in enkele gevalle Vader genoem (1:6; 14:1). Die Lam verwys na sy Vader $(2: 27 ; 3: 5,21)$. God se betrokkenheid by die proses van verlossing deur die offer van die Lam, sy Seun, plaas die fokus op sy rol as Vader. God is Vader in sy verhouding tot sy Seun, Jesus (Malina 1981:87; Woodward 1996:75). Seker die treffendse voorkoms van dié naam vir God is in 21:7 waar die vernuwing van die verbondsformule klink: “... en Ek sal sy God wees, en hy sal my seun wees".

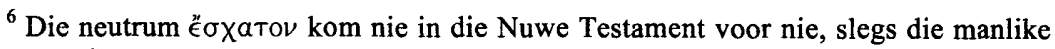

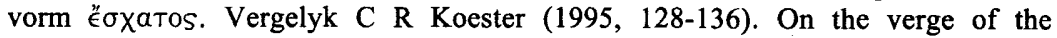
millennium: a history of the interpretation of Revelation.
} 
'n Mens sou kon sê dat die mysterium tremendum van God setel in die naam: die Een wat op die troon sit. Dié titel kom sewe keer voor in Openbaring $(4: 9 ; 5: 1,7 ; 13: 6,16 ; 7: 15 ; 21: 5)$ met enkele variasies in $4: 2,3 ; 7: 10 ; 19: 4$ en $20: 11$. Die troontoneel in $4: 1 \mathrm{vv}$ dien as basiese uitgangspunt. In die sentrum van die hemel setel God terwyl Hy regeer. Teenoor die politieke mag en religieuse pretensie van Rome, soos vergestalt in die keiserverering, plaas Openbaring die fokus op God se verhewenheid op sy troon. Hy alleen heers. Dit sê soveel van God se karakter maar ook nie sonder 'n sluier van bedekking nie. Hy wat regeer, heers met mag en regverdigheid, kontroleer die gang van die geskiedenis en begelei almal en alles tot hul voleindig. Die ringkomposisie van troon $(4: 2)$ tot troon $(21: 5-8 ; 22: 3)$ is treffend. Dit omarm Openbaring as Godboek (Charles 1993:85-97; Quarcoopome 1994:339-357; Williamson 1993). Ook in die fisiese beskrywings leer ons God só ken. Slegs toespelings of metaforiese simboliek kan op God van toepassing gemaak word omdat $\mathrm{Hy}$ onverdedigbaar is. Die waardevolle gesteentes (21:11, $18,19)$ en die reënboog om sy troon laat dink aan God se verhewe transendensie maar ook aan sy betrokkenheid by die mens. Die reënboog herinner aan God se verbond met Noag (Gen 9:12-17).

Die saamgestelde raam: die Een wat is en wat was en wat kom $(1: 4,8 ; 4: 8 ; 11: 17 ; 16: 5)$ gee by uitnemendheid uitdrukking aan God se ewige betrokkenheid by die geskiedenis van sy skepping. Dit is ' $n$ interpretasie van die Hebreeuse naam vir God: JHWH. 'n Soortgelyke uitleg van dié naam vind ons in die Ou Testament in Eksodus 3:14: "Ek is wat $\mathrm{Ek}$ is". In latere Judaïsme is hierdie interpretasies verstaan as 'n aanduiding van die ewigheid van God (Bauckham 1993:28; Filo, Mos 1:75). Die Palestynse Targum Pseudo-Jonatan parafraseer dié Naam tot "Ek is wat is en wat was en wat sal wees"7. Die Johannese weergawe: Die Een wat is en wat was en wat kom stem ooreen met dié van die Targum deurdat dit prioriteit verleen aan God se huidige bestaan maar verskil van alle moontlike parallelle deurdat die werkwoord "om te wees" in die derde deel vervang is deur "om te kom". God se bestaan setel nie net in sy abstrakte eksistensie nie, maar in sy betrokkenheid by die mens. Dit herinner ook aan die Ou-Testamentiese profetiese aankondigings dat God sal kom om te red en te oordeel (Bauckham 1993:29). Vroeë Christene het dié koms eskatologies geïnterpreteer na aanleiding van veral Psalms 96:13; 98:9; Jesaja 40:10; 66:15 en Sagaria 14:5.

Volgens die voorkomste van dié beskrywende titel vir God in Openbaring $(11: 17 ; 16: 5)$ blyk dit dat dit nie meer slaan op die toekoms

\footnotetext{
${ }^{7}$ Vergelyk Deuteronomium 32:29; Sibillynse Orakel 3:16. Die drievoudige formule vir God met die drie tydsaanduidings is ook van die Griekse gode vermeld. Moontlik het só 'n gebruik die Judaïstiese formule beïnvloed waar Openbaring waarskynlik sy agtergrond vind.
} 
nie, maar eskatologies reeds in vervulling gegaan het. God se eskatologiese betrokkenheid is 'n alreedse werklikheid. Openbaring 11:17 kreet dit só uit: "Ons dank U, Here God, Almagtige, u wat is en wat was, dat $\mathrm{U}$ nou u groot mag gebruik en as koning heers". God se eskatologiese heerskappy word 'n werklikheid deur sy koms in die offer van die Lam. Die futuristiese element is vervang deur dankbaarheid omdat God alreeds deur sy koms sy rol as heerser opgeneem het. Deur sy betrokkenheid volvoer God sy skepping tot sy bestemming. Hierdie titel beskryf by uitnemendheid God se voortgaande betrokkenheid by sy wêreld en die geskiedenis van die mensheid.

Volgens indirekte karakterisering kom God se dade in fokus. Sy heerskappy ontvou op aarde deur die oorwinning van die Lam. Volgens 5:7 ontvang die Lam die boek uit God se hand. Uit dié daad vloei die res van die ontvouing van sy heerskappy op aarde en in die geskiedenis voort. God laat dinge gebeur en Hy laat ook gebeure toe.

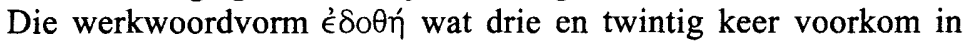
Openbaring, is 'n verdere aanduiding van God se dade (Rotz 1998:399). Die vier perderuiters $(6: 2,4,8)$ en die vier engele word slegs deur God toegelaat om hul sending te voltooi. Dit geld ook van die sprinkane $(9: 3$, $5)$. God laat selfs die vyandige magte toe om sy doel-eindes te verwesenlik $(13: 5,7,14,15)$.

Sommige dade van God sal in die toekoms plaasvind. In die nuwe Jerusalem sal God se teenwoordigheid oor sy eie oopsprei soos 'n tent. Sy woonplek is by die mense (21:3). By wyse van interpretasie sou 'n mens kon praat van God se shekina-teenwoordigheid. Hy sal' ook self by sy eie wees "as hulle God" (21:3). Die werklikheid dat God de jure alleenheerser is, ontplooi op grond van die Lam se oorwinning de facto op aarde (Boring 1989:148).

God se houding word geteken as Iemand wat op 'n troon sit. Sy sittende houding beklemtoon sy mag en heerskappy as koning (4:2). Dit staan skerp afgeteken teenoor die ontugtige Babilon wat op 'n dier as "troon" sit (17:3) (Williamson 1993:72). Direkte woorde deur God word op twee plekke in Openbaring aangetref. In 1:8 sê Hy: "Ek is die Alfa en die Omega, wat is en wat was en wat kom, die Almagtige"; en in 21:5-8: "Kyk, Ek maak alles nuut". Dié twee aanhalings (gedeeltelik) vorm 'n goddelike ringkomposisie wat die res van die inhoud omarm. Die inhoud beweeg van God na God: volgens hoofstukke 4 en 5 is Hy wat is en wat was en wat kom op die troon en saam met Hom die geslagte Lam, en in die slottoneel (22:5), verskyn God en die heersende Lam saam op die troon. God se heerskappy omspan almal en alles volgens Openbaring. Hy ken nie net die begin en die einde nie maar is die begin en einde.

Enkele opsommende slotopmerkings oor die resultate van interdividuele karakterisering is ter sake. God word gekarakteriseer in sy verhouding met andere. 
Mense, volgens Openbaring, kan in twee groepe geklassifiseer word: diegene wat God volg en Hom as heerser erken en daarteenoor diegene wat stelling inneem teen God saam met Satan. Hemelse aankondigings, profetiese verslae en oproepe tot bekering gee uitdrukking aan God se begeerte om gemeenskap te hê met die mens. God se stem word ook gehoor in die sewe briefboodskappe aan die gemeentes in KleinAsië (hfst 2,3) in die seëls, trompette, bakke en simboliek. Die mens se reaksie daarop deur geloof of verwerping is merkwaardig. Oordeel reflekteer oënskynlik die "donker" kant van God se karakter maar is wesenlik uitdrukking van sy geregtigheid. Die geslagte Lam reflekteer God se verlossingsbetrokkenheid en die seëls, trompette en bakke sy regverdige oordeelsbetrokkenheid. Verlossing en oordeel ontvou parallel aan mekaar in die geskiedenis.

Satan is deur Migael en sy engele verslaan in die hemel; daarom woed hy voort om oorlog te maak op aarde. Satan, die antichris en vals profeet se mag is nie absoluut nie, maar toegelaat deur God binne perke en slegs tydelik. Die leser se uitsig op die polariserende bose bring juis insig ten opsigte van God. Hy wat is en wat was en wat kom se ewige oorsprong, bestemming en betrokkenheid by die wêreld word in reliëf geplaas deur die gepolariseerde negatiewe tekening van die bose volgens Openbaring.

Ook die hemelse wesens, soos byvoorbeeld die vier lewende wesens, vier en twintig ouderlinge, engele en stemme, om enkeles te noem, stel God ten toon in hul diens en lofprysing. God, die betrokkene en Almagtige, se karakter word nog sigbaarder in die liedere en loftoesegginge van die hemelse wesens. Veral die engele mak God "sigbaar". Dit is ' $n$ engel wat Satan oorwin het in die hemel; wat Hom vasbind en in die onderaardse diepte gooi (20:1); wat die val van Babilon aankondig en voortgaan om die druiwetrosse te oes en in die parskuip van God se toorn te gooi. Hulle demonstreer God se verlossende en oordelende aktiwiteit op aarde.

Die vier vroulike karakters, volgens Openbaring, dra op 'n besondere wyse by tot die karakterisering van God. Isebel (2:20-21) se teenkanting teen God se "dienaars" bring God se eksklusiwiteit in reliëf. God moet onverdeeld gedien word - Hy deel geen lojaliteit vermeng met geestelike ontrou nie. Die onboetvaardiges moet boet vir hul onversetlikheid voor God. En die opgesmukte sedelose vrou (17:1-6) wat die rykes en magtiges verlei, plaas weer die fokus op God se alleenmag. In 'n oomblik vernietig Hy die magtiges, rykes en hul verleier. Die derde vrou "met die son as kleed om haar" (12:1) is as Messiaanse moeder deel van God se verlossingsplan. Haar moederbeeld bind die gebore Kind, God en God se mense hegter aan mekaar. Die betrokkenheid van Hom wat is en wat was en wat kom kom die intiemste tot uitbeelding in die bruid as metafoor van die kerk (gelowiges). God se "liefdesverhouding" 
met sy eie lewer vrug op wanneer die uiteinde as a bruilofsfees voorgestel word. Die aanstaande huwelik verbeeld op intieme wyse God se besondere betrokkenheid by sy eie.

\section{SLOTWOORD}

Deur direkte en indirekte (veral interdiwiduele) karakterisering van God volgens Openbaring is aangetoon dat $\mathrm{Hy}$ wat is en wat was en wat kom nie net as die veraf en transendente geteken word nie, maar die betrokkene by sy eie. Hy sit op sy troon, omring deur lewende wesens, ouderlinge en engele maar is verlossingsmatig betrokke by sy skepping. Sy titels beklemtoon sy mag, heerlikheid, ewigheid en regverdigheid. Hy is die Alfa en Omega, die Een wat op die troon sit, die Almagtige, Vader en die Een wat is en wat was en wat kom, die ewige betrokkene.

God beloof verlossing aan die getroues, maar ook straf vir die onverskilliges. Hy waak oor sy eksklusiwiteit en majesteit en duld nie sonde nie. Ook sy dade vertel wie God is. Hy werk deur hemelse wesens en laat selfs die bose toe om binne beperkte ruimte op te tree. Hy beheer en bepaal die geskiedenis volgens sy plan. Om die toekoms te ken, is nie bloot ' $n$ informatiewe ken nie, maar om in 'n lewende gemeenskap te leef met Hom wat betrokke is. Hy is die toekoms. Sy mag oorskry alle aardse mag en die klimaks van sy werke is die offergawe van die Lam.

Die "grootsheid" (in menslike terme) van God lê in sy betrokkenheid by die mens. Op grond van sy verlede en hede met die mens is daar ook 'n toekoms. God voorsien verlossing en seën en ontvang in die verhouding met die mens lofprysing en aanbidding. God se betrokkenheid is 'n teokratiese werklikheid waaruit die leser van Openbaring kan en moet leef. Tans is dié gemeenskap nog belemmerd en gedeeltelik totdat die volmaakte in die nuwe Jerusalem aanbreek.

\section{Literatuurverwysings}

Aune, D E 1986. The Apocalypse of John and the problem of genre. Semeia 22, 65-96.

$\mathrm{Bal}, \mathrm{M}$ 1985. Narratology: Introduction to the theory of narrative, $(\operatorname{Tr} \mathrm{C}$ van Boheemen) Toronto: University of Toronto Press.

Barr, D 1984. The Apocalypse as a symbolic transformation of the world: A literary analysis, Interpretation 38, 37-50.

Bauckham, R J 1993. The Theology of the Book of Revelation. Cambridge: University Press.

Beck, D R 1993. The narrative function of anonymity in Fourth Gospel characterization. Semeia 63, 143-158.

Beckwith, I T 1922. The Apocalypse of John. New York: Macmillan.

Boring, M E 1989. Revelation. Louisville: John Knox.

Bowman, J 1968. The First Christian drama: The Book of Revelation. Philadelphia: Westminster.

Burnett, F W 1993. Characterization and reader construction of characters in the Gospels. Semeia 63, 3-28. 
Charles, J D 1993. Imperial pretensions and the throne vision. Chriswell Theoligal Review 7, 85-97.

Chatman, S 1978. Story and discourse: Narrative structure in fiction and film. Ithaca: Cornell University Press.

Collins, A Y 1976. The combat myth in the Book of Revelation. Chicago: Harvard Theological Dissertations, 84.

-, 1977. The political perspective of the Revelation to John, $J B L$ 96, 241-256.

Cothenet, E 1995. Le Message de l'Apocalypse. Paris: Mame/Plon.

Day, L 1995. Three faces of a queen. Characterization in the book of Esther. Sheffield: Sheffield Academic Press.

De Silva, D A 1993. The construction and social function of a counter-cosmos in the Revelation of John. Forum 9, 47-61.

Donaldson, L E 1993. Cyborgs, Ciphers and sexuality: Re-theorizing literary and biblical character. Semeia 63, 81-96.

Du Rand, J A 1990. Johannese Perspektiewe: Inleiding tot die Johannese geskrifte. Midrand: Orion.

-, 1997. "Your kingdom come on earth as it is in heaven". The theological motif of the Apocalypse of John. Neotestamentica 31(1), 59-75.

Frend, W H L 1965. Martyrdom and persecution in the early church. Oxford: Blackwell.

Gill, C 1990. The character-personality distinction, in: Pelling C (ed), Characterization and individuality in Greek literature. Oxford: Clarendon.

Growler, D B 1993. Hospitality and characterization in Luke 11:37-54. A socio-narratological approach. Semeia 64, 21-35.

Harrington, W J 1993. Revelation. Collegeville: Liturgical Press.

Johnson, W S 1993. The reign of God in theological perspective. Interpretation 47, 127139.

Kealy, S P 1987. The Apocalypse of John. Wilmington: Michael Glazier.

Koester, C R 1995. On the verge of the millennium: A bistory of the interpretation of Revelation. World and World 15, 128-136.

Malina, B J 1981. The New Testament world. Atlanta: John Knox.

-, 1995. On the genre and message of Revelation: Star visions and sky journeys. Peabody: Hendrickson.

Martin, W 1986. "Flat characters" Recent theories of narrative. Ithaca: Carnell University.

McCracken, D 1993. Character in boundary: Bakhtin's interdividuality in biblical narratives. Semeia 63, 29-42.

Prince, G 1987. A dictionary of Narratology. Lincoln: University of Nebraska.

Quarcoopome, N O 1994. Thresholds and thrones. J Rel Afr 24, 339-357.

Reid, D G 1996. When God declares war. Christianity Today 40, 14-24.

Roberts, M (ed), 1948. The art of fiction and other essays. New York: Oxford University Press.

Rotz, C 1998. The One who sits on the throne. Individual perspectives of the characterization of God in the book of Revelation. Johannesburg: RAU (Unpublished D Litt et Phil).

Schüssler Fiorenza, e 1991. Vision of a just world. Minneapolis: Fortress.

Smalley, S S 1994. Thunder and love; John's revelation and John's community.

Milton Keynes: Word.

Swete, H B 1977. Commentary on Revelation. Grand Rapids: Kregel. 
Van Boheemen, C 1985. Narratology: Introduction to the theory of narrative. Toronto: University of Toronto.

Vanni, U 1991. Liturgical dialogue as a literary form in the Book of Revelation. New Testament Studies 37, 348-372.

Weinsheimer, J 1979. Theory of character: Emma. Poetics Today 1, 185-211.

Williamson, R L 1993. Thrones in the book of Revelation. Waco: Ssouth Baptist Theological Seminary.

Woodward, K L 1996. Hallowed be thee Name. Newsweek 127(25), 75. 